\title{
Effects of Nandrolone Decanoate and Resistance Exercise on Skeletal Muscle in Adult Male Rats
}

\author{
Efectos del Decanoato de Nandrolona y el Ejercicio de Resistencia \\ en el Músculo Esquelético de Ratas Machos Adultos \\ "Cynthia Dela Cruz; ** Leandro B Agati \& ${ }^{* *}$ Oduvaldo C. M. Pereira
}

DELA CRUZ, C.; AGATI, L. B. \& PEREIRA, O. C. M. Effects of nandrolone decanoate and resistance exercise on skeletal muscle in adult male rats. Int. J. Morphol., 30(2):613-620, 2012.

SUMMARY: The aim of this study was to compare the effects of resistance exercise associated or not with nandrolone decanoate (ND) on skeletal muscles and body mass of adult male rats. Training protocol consisted of 15 jump sessions, for $6 \mathrm{weeks}$. ND (5mg/kg) was administered twice a week. The exercise was effective in inducing respective enlargements in fiber areas of extensor digitorum longus and soleus muscles. ND associate with exercise was also able to induce increases in fiber areas these muscles. In untrained group that received nandrolone decanoate an improved in muscular parameters could be observed. In conclusion, the resistance exercise was able to promote an enlargement in fiber areas of both muscles studied without ND treatment, indicating that after a period of time of adaptation to exercise, the muscular effects caused by ND could be achieved in the same way by exercise, without ND and without risks for health.

KEY WORDS: Anabolic Androgenic Steroids; Extensor Digitorum Longus; Nandrolone Decanoate; Resistance Training; Skeletal Muscles; Soleus.

\section{INTRODUCTION}

Anatomically, the human skeletal muscle is a heterogeneous tissue composed of functionally diverse fiber types. This mixture of different fiber types enables the muscle to fulfill a variety of functional demands. An additional unique feature of skeletal muscle is an ability to alter its phenotypic profile in response to specific stimuli (Pette \& Staron, 2001, Campos et al., 2002). As the majority of professional or amateur athlete aim to reach his maximal performance, for this these athletes and others need to achieve a balance between training leads (intensity, volume and recovery periods) which allows them to optimize their physiological and psychological capacities and as consequence, in response to exercise, the increase muscle mass can be attributed to muscular hypertrophy and also to the formation of new fiber (Kadi et al., 1999). In this sense, resistance training has been studied extensively (Schiaffino \& Reggiani, 1996; Bottinelli \& Reggiani, 2000; Fluck \& Hoppeler, 2003; D'Antona et al., 2006), and now is well known that both muscle hypertrophy - quantitative mechanism - and a shift in fiber type distribution - qualitative mechanism -could be influenced by training.
Anabolic androgenic steroids (AAS) were first used by athletes in the mid 1950s and by the 1960s their use was widespread to build muscles and boost their athletic performance; the anabolic steroid abuse among athletes ranges between $1 \%$ and $6 \%$ (Hartgens \& Kuipers, 2004). In spite of the side effects of this compounds - fluid retention, elevated blood pressure, sleeplessness, increased irritability, decreased libido, increased appetite, enhanced transpiration, increased feeling of well being, alopecia and the occurrence of gynecomastia (Hartgens \& Kuipers; Maravelias et al., 2005) athletes and others (adolescents) have been taking these synthetic substances and sometimes, even at supraphysiological levels, but there is little question if the exogenous administration of testosterone and derivates results in hypertrophy when given to non-exercising persons, and also if it augments exercise-induced hypertrophy when combined with resistance exercise (Bhasin et al., 1996, Sinha-Hikin et al., 2002, Wilkinson et al., 2006).

In the current study we evaluated the possible effects of resistance training and AAS isolated, and their association 
on development of body mass, on corticosterone and testosterone levels and on extensor digitorum longus (EDL) and soleus muscles morphology, in adult male rats.

\section{MATERIAL AND METHOD}

Thirty-two adult male Wistar rats $(300-350 \mathrm{~g})$ were housed in groups of four per cage in a controlled environment with temperature at $25+1{ }^{\circ} \mathrm{C}$; humidity of $55+5 \% ; 12 \mathrm{~h} \mathrm{light/}$ dark cycle (lights on at 6:00 a.m.) and free access to regular lab chow and tap water. The rats were divided randomly into four groups (8 animals/group):

-Vehicle/Untrained (VU);

-Nandrolone/Untrained (NU);

-Vehicle/Trained (VT);

-Nandrolone/Trained (NT).

In the anabolic group (NU and NT) the animals were treated with nandrolone decanoate (Deca-Durabolin ${ }^{\circledR}$ ) $5 \mathrm{mg} /$ $\mathrm{kg}$ and the vehicle group (VU and VT) received ground-nut

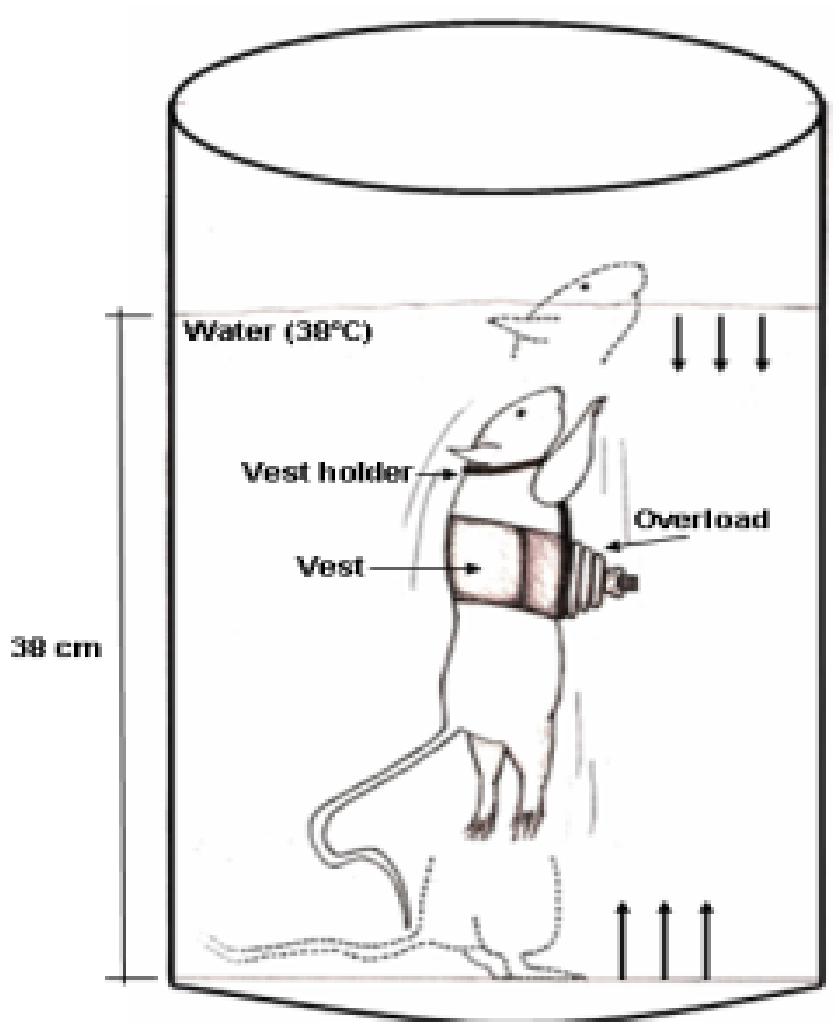

Fig. 1. Sketch of the resistance training apparatus. Image kindly provided by Andreo Fernando Aguiar. oil + propylene glycol, i.m., twice a week, for six weeks. Both groups of trained animals (VT and NT) were submitted to high-intensity resistance exercise protocol for six weeks. The employed dose of nandrolone decanoate is comparable to that frequently used by athletes (Pope \& Katz, 1988).

The body weights at the beginning of the treatment/ training and the end of the experimental period were determined in animals from all experimental groups in order to calculate the body mass variation during the protocol.

The animals used in the present study were maintained in accord with the Ethical Principles in Animal Research adopted by the Brazilian College of Animal Experimentation and approved by Institute of Biosciences / UNESP-Botucatu Ethical Committee for Animal Research (Protocol number 029/06).

Training protocol. The animals of the trained experimental groups were submitted individually to jump sessions in a PVC cylinder $50 \mathrm{~cm}$ in height and $25 \mathrm{~cm}$ in diameter, containing water at $30^{\circ} \mathrm{C}$ to a depth of $38 \mathrm{~cm}$. During the first week the animals from the training groups were adjusted to the water. This adjustment consisted of three sessions of weightlifting (once a day, for three alternate days) in water at $30^{\circ} \mathrm{C}+2^{\circ} \mathrm{C}$, with incremental number of sets (two to four) and repetitions (five to ten) and 30 seconds of rest between sets, carrying a load equivalent to $50 \%$ of body weight strapped to the chest. The sessions were performed between $11 \mathrm{am}-1 \mathrm{pm}$ and on the last day of the adjustment period the animals were performing four series of ten repetitions (Cunha et al., 2005; 2006). Subsequently, the rats were submitted to a high-intensity resistance training every 2 days for 5 weeks. During the first 2 weeks of training, the animals performed 4 sets of 10 jumps per set carrying a load equivalent to $50 \%$ of body weight strapped to the chest, with 30 seconds rest between sets. In the third and fourth training weeks, the animals performed the same exercise carrying a load weighing $60 \%$ of body weight, and in the last week, this load was adjusted to $70 \%$ of body weight (Fig. 1 and Table I).

Forty-eight hours after the end of the training/ treatment the animals from all experimental groups were anesthetized with sodium pentobarbital $(40 \mathrm{mg} / \mathrm{kg}$, i.p.) and blood samples were collected from the abdominal aorta into heparin-coated syringes (always between 8:30 and 9:30 a.m.), for plasma corticosterone and testosterone determination. Immediately after this procedure, the animals were killed by an overdose of sodium pentobarbital and the soleus and EDL skeletal muscles were weighed and fragments of the medial third of each muscle were isolated and frozen in liquid nitrogen and stored in a freezer at $-80^{\circ}$ $\mathrm{C}$ to future analysis. 
Table I . Training protocol.

\begin{tabular}{|c|c|c|c|}
\hline Training Weeks & Training Days & Training Sequence & $\begin{array}{c}\text { Overload in relation to } \\
\text { body mass }\end{array}$ \\
\hline \multirow{3}{*}{$\begin{array}{c}1 s^{t} w_{e e k} \\
\text { (Adaptation) } \\
\end{array}$} & $1^{\text {st }}$ & $2 \times 5$ jumps & $\mathbf{5 0 \%}$ \\
\hline & $\mathbf{3}^{d}$ & $4 \times 5$ jumps & $\mathbf{5 0 \%}$ \\
\hline & $5^{\text {th }}$ & $4 \times 9$ jumps & $\mathbf{5 0 \%}$ \\
\hline$\underline{2}^{\text {nd }}$ and $3 r^{d}$ weeks & 6th to $15 t h$ & $4 \times 10$ jumps & $\mathbf{5 0 \%}$ \\
\hline $4^{\text {th }} a_{n d} 5^{\text {th }} w_{e e k s}$ & $16^{\text {th }}$ to $25^{\text {th }}$ & $4 \times 10$ jumps & $60 \%$ \\
\hline$\underline{6^{\text {th }} w_{e e k}}$ & $26 t h$ to $30 t h$ & $4 \times 10$ jumps & $70 \%$ \\
\hline
\end{tabular}

Corticosterone level. Blood was centrifuged (2,500 rpm for $20 \mathrm{~min}$ at $2^{\circ} \mathrm{C}$ ) and the plasma was assayed by radioimmunoassay, using the Coat-A-Count ${ }^{\circledR}$ Rat Corticosterone Kit (Diagnostic Products, USA). The test had an analytical sensitivity of $5.7 \mathrm{ng} / \mathrm{ml}$. The intra-assay coefficient of variance was less than $7.0 \%$.

Testosterone level. Blood was centrifuged (2,500 rpm for $20 \mathrm{~min}$ at $2^{\circ} \mathrm{C}$ ) and the plasma was assayed by radioimmunoassay, using the Coat-A-Count ${ }^{\circledR}$ Rat Total Testosterone Kit (Diagnostic Products, USA). The test had an analytical sensitivity of $4.0 \mathrm{ng} / \mathrm{ml}$. The intra-assay coefficient of variance was less than $7.0 \%$.

EDL and Soleus analyses. For morphological studies of the EDL and soleus muscles, transversal cryosections approximately $10 \mu \mathrm{m}$ thick were cut in a cryostat at $-20^{\circ} \mathrm{C}$ and submitted to hematoxilyn-eosin staining. Muscle fiber area was measured using a compound microscope attached to a computerized imaging analysis system (Qwin, Leica, Nussloch, Germany). Microscopic fields were captured by the program and all the whole fibers of this field were measured. At least 100 fibers from each muscle were measured.

\section{Body mass variation}

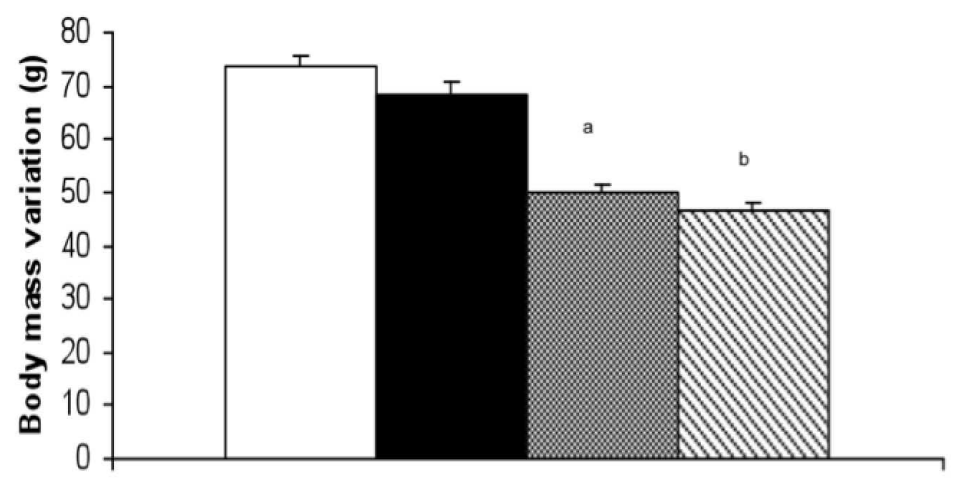

Statistical Analysis. Statistical analyses were performed using a software package (SPSS for Windows, version 13.0). To ensure that the data were stable, the statistical procedure was accomplished after the preliminary study of the variable related to normality and equality of variance among all groups, with statistical power of $80 \%$ for the comparisons realized. Statistical comparisons among the groups were made using analysis of variance (ANOVA) for the 2-factor model (Zar, 1999) for body weight and the quantification of hormones and muscle fiber area. When significant main effects were revealed, specific differences were assessed using Tukey's post hoc comparisons. Data are expressed as mean \pm SD. Differences were considered significant for $\mathrm{p}<$ 0.05 .

\section{RESULTS}

Body weight gain. The body weight gain was smaller in the VT and NT groups in relation to VU and NU groups, respectively ( $<0.05$ - Fig. 2). To assess the size of the training/treatment effect Cohen's $d$ was calculated with scores above 0.80 representing large effects.

\begin{tabular}{|l|}
\hline$\square$ Vehicle Untrained \\
Nandrolone Untrained \\
⿴囗Vehicle Trained \\
\& Nandrolone Trained
\end{tabular}

Fig. 2. Body mass variation between the beginning and the end of the experimental period in animals from the different experimental groups.

Values expressed as mean + SEM of 8 animals/group.

a Significantly different in relation to vehicle untrained group, $\mathrm{p}<0.05$ b Significantly different in relation to nandrolone untrained group, $\mathrm{p}<0.05$ 
Table II. Corticosterone level at the end of the experimental period in animals from the different experimental groups.

\begin{tabular}{ccccc}
\hline Groups & Vehicle Untrained & $\begin{array}{c}\text { Nandrolone } \\
\text { Untrained }\end{array}$ & Vehicle Trained & $\begin{array}{c}\text { Nandrolone } \\
\text { Trained }\end{array}$ \\
\hline $\begin{array}{c}\text { Costicosterone levels } \\
(\mathbf{n g} / \mathbf{m L})\end{array}$ & $319.67+56.71$ & $370.05+65.75$ & $453.11+40.13$ & $372.99+16.04$ \\
\hline
\end{tabular}

Values expressed as mean + SEM of 8 animals/group. There was no significant difference among the groups, $\mathrm{p}>0.05$.

Corticosterone level. At the end of the experimental period, a non-significant alteration was observed in the corticosterone level among the experimental groups (Table II).

Testosterone level. The testosterone level showed an increase in the VT group, and a significant decrease in both groups that received nandrolone decanoate (UN and TN) (Fig. 3).
EDL and Soleus analyses. In all experimental groups, EDL and soleus muscles showed normal morphology, which included fibers with polygonal aspect and peripheral nuclei (Figs. 4 and 5). The NU, VT and NT groups showed significant enlargement of the EDL muscle fiber area in relation to VU group $(\mathrm{p}<0.05)$. The fiber area of the soleus muscle in the VT, NT and NU groups rose in relation to the VU group $(p<0.05)$, while the NU and NT trained groups were also augmented in relation to the VT group $(\mathrm{p}<0.05$, Table III).

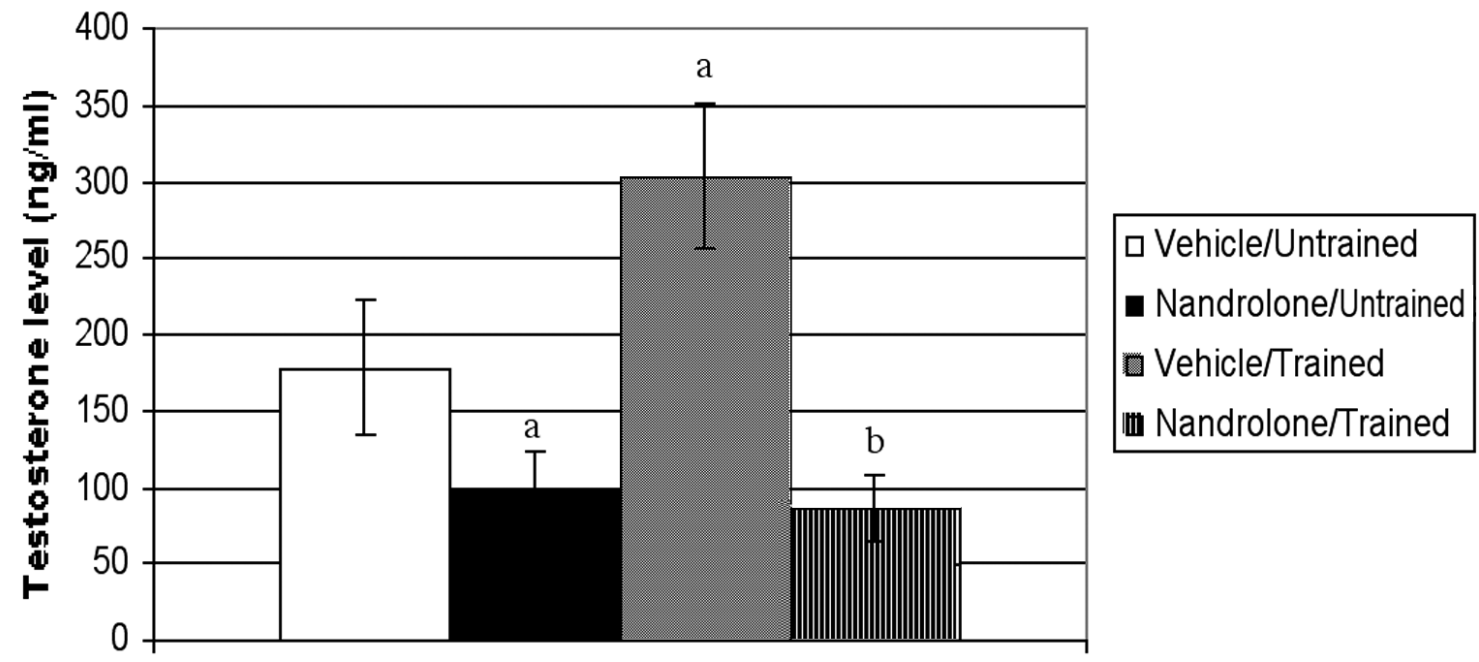

Fig. 3. The testosterone level at the end of the experimental period.

Table III. Muscle fiber area of EDL and soleus muscles isolated from animals of the different experimental groups.

\begin{tabular}{lcc}
\hline Groups & EDL Fiber area $\left(\mu \mathbf{m}^{2}\right)$ & Soleus fiber area $\left(\mu_{\mathbf{m}}{ }^{2}\right)$ \\
\hline Vehicle untrained & $1324.0 \pm 23.30^{\mathrm{A}}$ & $1946.1 \pm 21.14^{\mathrm{A}}$ \\
Untrained nandrolone & $1502.5+16.27^{\mathrm{B}}$ & $2907.0+33.38 \mathrm{C}$ \\
Vehicle trained & $1550.7 \pm 26.63^{\mathrm{B}}$ & $2174.7 \pm 25.13 \mathrm{~B}$ \\
Nandrolone trained & $1476.6+27.89^{\mathrm{B}}$ & $2892.9+33.37 \mathrm{C}$ \\
\hline
\end{tabular}

Values expressed as mean + SEM of 8 animals/group.

Different capital letters indicate significant vertical differences among the groups $\mathrm{p}<0.05$. 

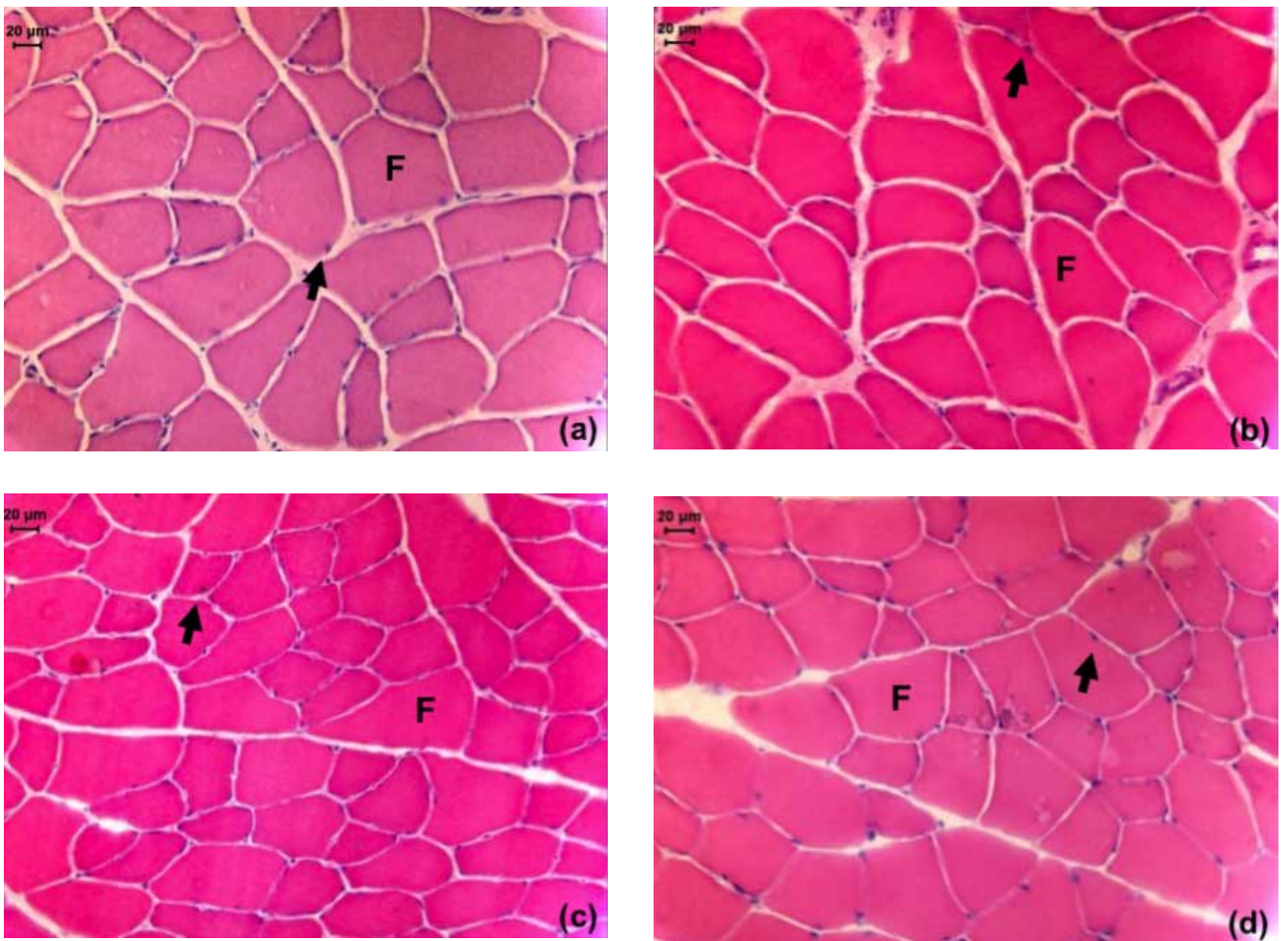

Fig. 4. Transverse section of EDL muscle submitted to haematoxilin and eosin (HE) stain. Normal muscle fibers with polygonal aspect (F) and peripheral nuclei (arrow). a. Vehicle untrained; b. Vehicle trained: c. Nandrolone untrained; d. Nandrolone trained groups.
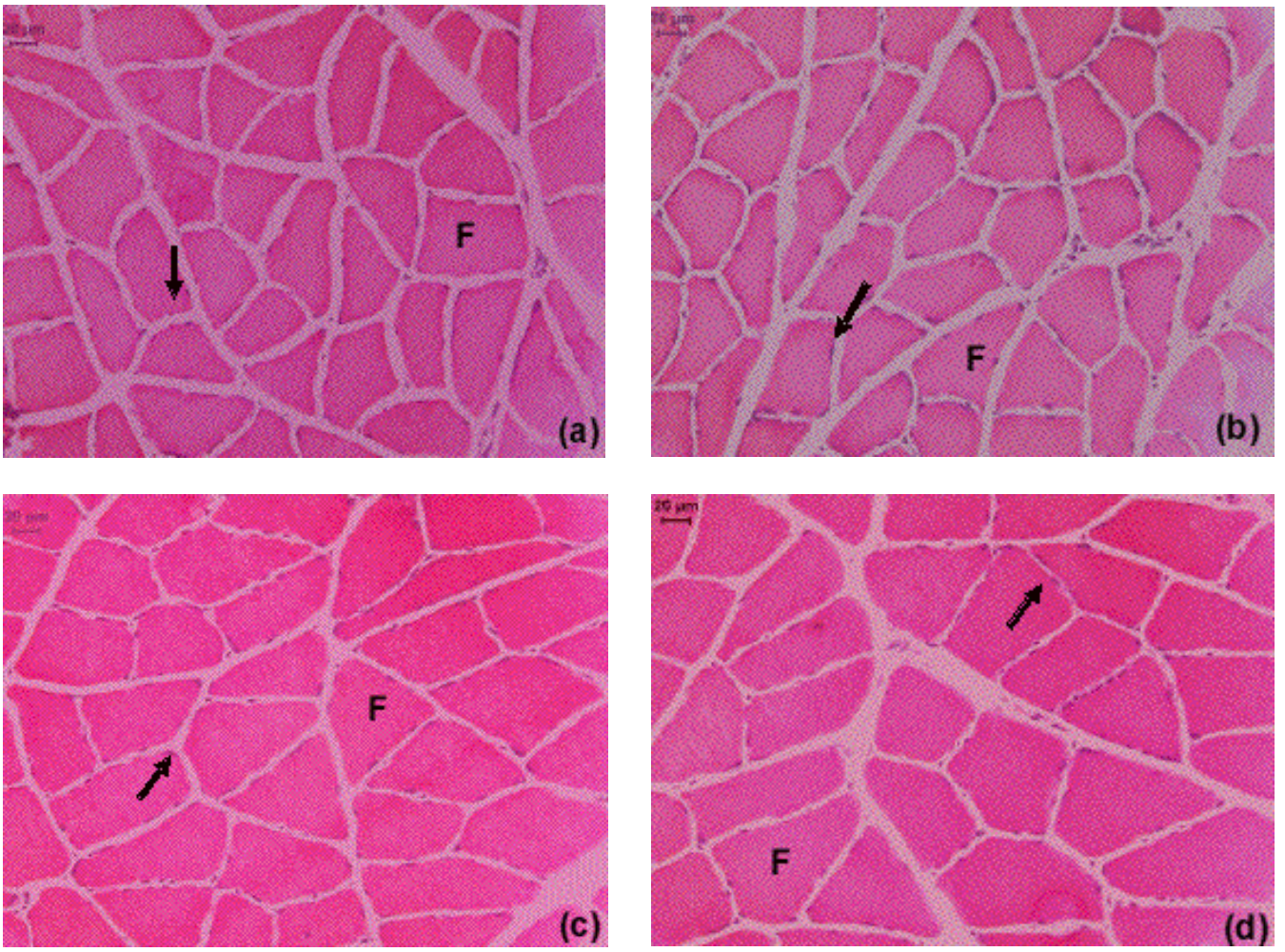

Fig. 5. Transverse section of soleus muscle submitted to haematoxilin and eosin (HE) stain. Normal muscle fibers with polygonal aspect $(\mathrm{F})$ and peripheral nuclei (arrow). a. Vehicle untrained; b. Vehicle trained; c. Nandrolone untrained; d. Nandrolone trained groups. 


\section{DISCUSSION}

The resistance training used in these study promoted a decrease in the body mass gain and was effective at raising the testosterone level and at augmenting the fiber areas of both EDL and soleus muscles. As we expected, the AAS also produced a decrease in the body mass gain and a rise in the muscle fiber areas of both EDL and soleus muscles as associated with resistance training as in untrained animals, but was able to promote a decrease in the testosterone levels of both groups that received AAS (untrained and trained). It appears that the acute response to resistance exercise was more critical to tissue growth and remodeling than chronic changes in resting hormonal concentrations, given that many studies have demonstrated the absence of a significant change after resistance training despite increases in muscle strength and hypertrophy (Kraemer \& Ratamess, 2005). A decrease in the body mass gain promoted by resistance training and AAS might be related to intense lipid use during the recovery period following high-intensity glycogen-depleting exercise, and the physiological actions of the anabolic androgenic steroids, such as their ability to cause nitrogen retention and positive protein metabolism, thereby leading to increased protein synthesis and muscle mass (Feldkoren \& Andersson, 2005). On this sense, it has been suggested that supraphysiological doses of anabolic androgenic steroids can inhibit body growth and weight gain (Carson et al., 2002).

Besides the corticosterone elevation in the VT group, it did not show a statistical difference among the groups, indicating that these animals were not exposed to a highstress situation. These data may supported by the results observed by Cunha et al. ( 2006), since a 6-week treatment/ training protocol was utilized.

Studies have shown that the use of AAS may dramatically lower serum gonadotropins (Hartgens \& Kuipers; Hug et al., 2003; Maravelias et al.), since AAS are derived from testosterone and exerts important effects on the sex hormones. Furthermore, they suppress the hypothalamic-pituitary-gonad axis, which acts as a feedback system. Consequently, exogenous administration of AAS disturbs the endogenous production of testosterone and gonadotropins (Hickson et al., 1994). These findings corroborate with our results, since both groups that received AAS (UN and TN) showed a decrease in testosterone level. The exogenous testosterone derivative (AAS) probably was able to cause a negative feedback in response to gonadotropins, and was thus responsible for the observed drop in circulating testosterone levels.
Nandrolone decanoate, used in the present study, is a steroid that presents an anabolic activity; therefore, most of the drug binds to its receptor in the muscles, decreasing the circulating portion. On the other hand, the resistance training was able to elevate the testosterone level among animals that were submitted only to training. The magnitude of testosterone elevation after the resistance training has been shown to be affected by the muscle mass involved (i.e. exercise selection), intensity and volume, nutritional intake, training experience, and is independent of the individual's absolute level of muscular strength. Based on these data, it appears that programs designed to stimulate testosterone secretion should be structured around large muscle-mass exercise (McClung et al., 2005).

Physical exercise has been implicated in the modulation of muscle fiber behavior since the training utilized in the present study was effective at enlarging fiber cross-sectional area of both EDL and soleus muscles. However, the effects of different training programs on muscle structure and mechanics remain controversial (Hamalainen \& Pette, 1993; Jansson et al., 1990). No significant differences in EDL or soleus muscles mass were found when the training was performed 5 days/week for 6 weeks (Cunha et al., 2006). In this context, the interaction suggested between hormones and muscle cell receptors could, in theory, have an effect on the subsequent recovery phase and stimulate hypertrophy through increased protein synthesis (Kraemer et al., 1990). In relation to anabolic steroids and muscle response, the many variables important for consideration include species, age, sex, and muscle type (Ahtiainen et al., 2003; Antonio et al., 1999; Carson et al.). There is little question that exogenous administration of testosterone at supraphysiological levels results in hypertrophy when given to non-exercising persons, and also augments exercise-induced hypertrophy when combined with resistance exercise (Bhasin et al.; Schiaffino \& Reggiani; Tamaki et al., 2000).

In this way, the principal find of this study was that resistance training was able to cause benefic effects for health like decrease in the body mass gain, a rising in the testosterone level and at augmenting the fiber areas of both EDL and soleus muscles without AAS. Additionally, despite the side effects and restrictions on use, our results also can provide support for clinical research of these compounds and perhaps could be a new solution of this new century's lifestyle, given the current use of anabolic steroid by sedentary people and the elderly. In this sense, more research involving physical exercise, different types of training protocols, doses of AAS and untrained subjects should be tested, in order to understand these interactions and suggest the best protocol and treatment for specific situations. 
ACKNOWLEDGMENTS: We are grateful to Eunice Oba, Ph.D., from the Department of Animal Reproduction, UNESP - Univ Estadual Paulista, Botucatu, Sao Paulo, Brazil, for helping in corticosterone determination and also to Maeli Dal Pai-Silva, Ph.D., from the Department of
Morphology, UNESP - Univ Estadual Paulista, Botucatu, Sao Paulo, Brazil, for helping in morphological and biochemical analyses in the muscles. Financial support was provided by the Coordenação de Aperfeiçoamento de Pessoal de Nível Superior - CAPES to Cynthia Dela Cruz.

DELA CRUZ, C.; AGATI, L. B. \& PEREIRA, O. C. M. Efectos del decanoato de nandrolona y el ejercicio de resistencia en el músculo esquelético de ratas machos adultos. Int. J. Morphol., 30(2):613-620, 2012.

RESUMEN: El objetivo de este estudio fue comparar los efectos del ejercicio de resistencia con o sin decanoato de nandrolona (DN) en el músculo esquelético y la masa corporal de ratas macho adultas. El protocolo de entrenamiento consistió en 15 sesiones durante 6 semanas de saltos. DN 5mg/kg se administró dos veces durante la semana. El ejercicio fue efectivo para inducir un aumento en el área de las fibras de los músculos extensor largo de los dedos y sóleo. El DN asociado con el ejercicio fue capaz de inducir un aumento en el área de las fibras de los músculos. En el grupo de DN sin entrenamiento, se observó un aumento en los parámetros musculares evaluados. El ejercicio de resistencia sin DN fue capaz de promover un aumento en el área de las fibras de los músculos, lo que indica que después de un período de adaptación al ejercicio, el efecto en los músculos causada por la DN se logró por el ejercicio, sin una gestión DN y los consiguientes peligros para la salud.

PALABRAS CLAVE: Anabólicos; Musculo Esqueléticos; Músculo extensor largo de los dedos; Músculo sóleo; Decanoato de nandrolona; Entrenamiento de resistencia.

\section{REFERENCES}

Ahtiainen, J. P.; Pakarinen, A.; Kraemer, W. J. \& Hakkinen, K. Acute hormonal and neuromuscular responses and recovery to force vs maximum repetitions multiple resistance exercises. Int. J. Sports Med., 24: 410-8, 2003.

Antonio, J.; Wilson, J. D. \& George, F. W. Effects of castration and androgen treatment on androgen-receptor levels in rat skeletal muscles. J. Appl. Physiol., 87: 2016-9, 1999.

Bhasin, S.; Storer, T. W.; Berman, N.; Callegari, C.; Clevenger, B. \& Phillips, J., Bunnel, T. J., Tricker, R., Shirazi, A. \& Casaburi, $\mathrm{R}$. The effects of supraphysiologic doses of testosterone on muscle size and strength in normal man. N. Engl. J. Med., 335:1-7, 1996.

Bottinelli, R. \& Reggiani, C. Human skeletal muscle fibres: molecular and functional diversity. Prog. Biophys. Mol. Biol., 73:195-262, 2000.

Campos, G. E. R., Leucke, T. J., Wendlin, H. K., Toma, K., Hagerman, F. C. \& Murray, T. F., Ragg, K. E., Ratamess, N. A., Kraemer, W. J. \& Storon, R. S. Muscular adaptations in response to three different resistance-training regimens: specificity of repetition maximum training zones. Eur. J. Appl. Physiol., 88: 50-60, 2002.

Carson, J. A.; Lee, W. J.; McClung, J. \& Hand, G. A. Steroid receptor concentration in aged rat hindlimb muscle: effect of anabolic steroid administration. J. Appl. Physiol., 93:242-50, 2002 .

Cunha, T. S.; Tanno, A. P.; Marcondes, F. K.; Perez, S. E. \& SelistreAraújo, H. S. Nandrolone administration does not promote hypertrophy of soleus muscle in rats. Arq. Bras. Endocrinol. Metabol., 50:532-40, 2006.

Cunha, T. S.; Tanno, A. P.; Costa Sampaio Moura, M. J; \& Marcondes, F. K. Influence of high-intensity exercise training and anabolic androgenic steroid treatment on rat tissue glycogen content. Life Sci., 77: 1030-43, 2005.

D’Antona, G., Lanfranconi, F., Pellegrino, M. A., Brocca, L., Adami, R. \& Rossi, R.; Moro, G., Miotti, D., Canepari, M. \& Bottinelli, R. Skeletal muscle hypertrophy and structure and function of skeletal muscle fibers in male body builders. $J$. Physiol., 570:611-27, 2006.

Feldkoren, B. I. \& Andersson, S. Anabolic-androgenic steroid interaction with rat androgen receptor in vivo and in vitro: A comparative study. J. Steroid. Biochem. Mol. Biol., 94: 481-7, 2005.

Fluck, M. \& Hoppeler, H. Molecular basis of skeletal muscle plasticity - from gene to form and function. Rev. Physiol. Biochem. Pharmacol., 146:159-216, 2003.

Hamalainen, N. \& Pette, D. The histochemical profiles of fast fiber types IIB, IID, and IIA in skeletal muscle of mouse, rat, and rabbit. J. Histochem. Cytochem., 41:733-43, 1993.

Hartgens, F. \& Kuipers, H. Effects of androgenic-anabolic steroids in athletes. Sports Med., 34:513-54, 2004.

Hickson, R. C., Hidaka, K., Foster, C., Falduto, M. T. \& Chatterton R. T. Jr. Successive time courses of strength development and steroid hormone response to heavy-resistance training. J. Appl. Physiol., 76: 663-670, 1994. 
Hug, M.; Mullis, P. E.; Vogt, M.; Ventura, N. \& Hoppeler, H. Training modalities: over-reaching and over-training in athletes, including a study of the role of hormones. Best. Pract. Res. Clin. Endocrinol. Metabol., 17: 191-209, 2003.

Jansson, E.; Esbjornsson, M.; Holm, I. \& Jacobs, I. Increase in the proportion of fast-twitch muscle fibres by sprint training in males. Acta Physiol. Scand., 140: 359-63, 1990.

Kadi, F.; Eriksson, A.; Holmner, S. \& Thornell, L. E. Effects of anabolic steroids on the muscle cells of strength-trained athletes. Med. Sci. Sports Exerc., 31:1528-34, 1999.

Kraemer, W. J.; Marchitelli, L.; Gordon, S.E.; Harman E.; Dziados, J. E.; Mello, R.; Frykman, P.; McCurry, D. \& Fleck, S. J. Hormonal and growth factor responses to heavy resistance exercise protocols. J. Appl. Physiol., 69:1442-450, 1990.

Kraemer, W. J. \& Ratamess, N. A. Hormonal responses and adaptations to resistance exercise and training. Med.Sci. Sports Exerc., 35: 339-61, 2005.

Maravelias, C.; Dona, A.; Stefanidou, M. \& Spiliopoulou. Adverse effects of anabolic steroids in athletes: A constant threat. Toxicol. Lett., 158:167-75, 2005.

McClung, J. M.; Mehl, K. A.; Thompson, R. W.; Lowe, L. L. \& Carson, J. A. Nandrolone decanoate modulates cell cycle regulation in functionally overloaded rat soleus muscle. Am. J. Physiol. Regul. Integr. Comp. Physiol., 288; R1543-R1552, 2005.

Pette, D. \& Staron, R. S. Transitions of muscle fiber phenotypic profiles. Histochem. Cell. Biol., 115: 359-72, 2001.

Pope, H. G. \& Katz, D. L. Affective and psychotic symptoms associated with anabolic steroid use. Am. J. Psychiatry, 145: 487-90, 1988.

Schiaffino, S. \& Reggiani, C. Molecular diversity of myofibrillar protein: gene regulation and functional significance. Physiol. Rev., 76: 371-423, 1996.

Sinha-Hikin, I.; Artaza, J.; Woodhouse, L.; Gonzales-Cadavid, N.; Singh, .B.; Lee, M. I.; Storer, T. W.; Casaburi, R.; Shen, R. \& Bhasin, S. Testosterone-induced increase in muscle size in healthy young men is associated with muscle fiber hypertrophy. Am. J. Physiol. Endocrinol. Metab., 283: E154-E164, 2002.

Tamaki, T.; Uchiyama, S.; Uchiyama, Y.; Akatsuka, A.; Roy, R. R. \& Edgerton, V. R. Anabolic steroids increase exercise tolerance. Am. J. Physiol. Endocrinol. Metabol., 280: E973-E981, 2001.

Wilkinson, S. B.; Tarnopolsky, M. A.; Grant, E. J.; Correia, C. E. \& Phillips, S. M. Hypertrophy with unilateral resistance exercise occurs without increases in endogenous anabolic hormone concentrations. Eur. J. Appl. Physiol., 98:546-55, 2006.
Zar, J. H. Biostatistical analysis. $4^{\text {th }}$ ed. Prentice-Hall. New Jersey, Upper Saddle River, 1999.

Correspondence to:

Cynthia Dela Cruz, MSc

Division of Human Reproduction

Hospital das Clínicas, UFMG

Av. Alfredo Balena, 110, $9^{\circ}$ andar norte

30130-100

Belo Horizonte, MG,

BRAZIL

Phone: 5531 3409-9485

Fax: $55313409-9299$

E-mail address: delacruzfc@gmail.com

Received: 18-10-2011

Accepted: 29-02-2012 